\title{
Combining insights into reproduction and gear selectivity to enhance management advice for Encrasicholina heteroloba (Engraulidae) in the west coast of Sri Lanka
}

\author{
N. M. P. S. Navarathne and D. C. T. Dissanayake* \\ Department of Zoology, University of Sri Jayewardenepura, Gangodawila, Nugegoda, \\ Sri Lanka. \\ *Correspondence (chamari@ @jp.ac.lk) \\ https://orcid.org/0000-0001-8270-1641
}

\begin{abstract}
Encrasicholina heteroloba belonging to the family Engraulidae is a commercially important fish species in the smallscale artisanal fisheries in Sri Lanka. Fishery, reproductive biology and gillnet selectivity pattern of E. heteroloba were assessed using the data collected from the Negombo fish landing site on the west coast of Sri Lanka from January to December 2015 in order to provide baseline information such as catch rate, total production, reproductive seasonality, size at first sexual maturity (L50) and gear selectivity pattern of this data poor fishery. E. heteroloba are mainly exploited using drift gillnets of $1.1 \mathrm{~cm}, 1.2$ $\mathrm{cm}$ and $1.8 \mathrm{~cm}$ stretched mesh sizes. Females spawn throughout the year reporting a peak spawning in July. The sizes at first sexual maturity of E. heteroloba male and female are $7.40 \mathrm{~cm}$ and $7.45 \mathrm{~cm}$, respectively. The gillnet selectivity study revealed that the optimum length ( $\mathrm{L}_{\mathrm{opt}}$ ) and selection range of E. heteroloba varied with mesh sizes and estimated $\mathrm{L}_{\mathrm{opt}}$ for $1.0 \mathrm{~cm}, 1.2 \mathrm{~cm}$ and $1.8 \mathrm{~cm}$ mesh sizes were $5.6 \mathrm{~cm}, 6.4 \mathrm{~cm}$ and $9.2 \mathrm{~cm}$, respectively. We suggest to promote use of $1.8 \mathrm{~cm}$ mesh gill nets as a higher percentages of immature individuals are landed when smaller mesh $(<1.2 \mathrm{~cm})$ gill nets are used. The findings of this study will be useful to manage E. heteroloba stocks on the west coast of Sri Lanka.
\end{abstract}

Key words: Gillnet selectivity, Mean size at sexual maturity, optimum length, selection range

\section{INTRODUCTION}

Anchovies belonging to the family Engraulidae are small pelagic fish that often forms large shoals (Santaclara 2006). Globally, there are around 140 species of anchovies belonging to 17 genera and they are widely distributed in the Indian, Atlantic and Pacific Oceans and Mediterranean Sea (Lavoue et al. 2010). Anchovies are relatively short-lived species (Chayakul, 1990) and are considered as ecologically and economically important components of many marine ecosystems, particularly in upwelling regions (Barange et al. 2009).

Anchovies make a notable contribution to the world marine capture fisheries production $(\sim 10 \%)$ and its contribution in 2016 was 6.5 million tonnes. Peruvian anchovy (Engraulis ringens), Japanese anchovy (Engraulis japonicus) and European anchovy (Engraulis encrasicolus) are the most dominant species in the global anchovy catches (FAO 2018).
Anchovy is one of the dominant species in the coastal capture fishery in Sri Lanka. Although accurate catch statistics of anchovies are not available, it is reported that their contribution to the total coastal marine fishery production is being around 15 to 20\% (MFAR, 2015). Anchovies are mainly exploited in the coastal waters around Sri Lanka using small mesh gill nets and beach seines. Although, the catching of anchovy is a highly seasonal activity in many parts of the country, there is a year around fishery on the west coast of Sri Lanka. However, up to now there has not been a routine monitoring or any management measures in this fishery. Therefore, baseline information such as catch rates, total landings and the seasonal pattern of the fishery is yet to be known.

Insights into fishing activities, stock status and biology, more specifically reproductive biology of fishes are essential to implement evidence based fisheries management plan (Anger, 2006). Further, there is considerable attention to improve the size and species selectivity of commercial fishing gear as a measure of sustaining exploited fish stock

This work licensed under a Creative Commons Attribution-NonCommercial 4.0 International License 
(Stewart, 2001). However, no information related to such aspects is available for the anchovy fishery in Sri Lanka. Therefore, this study was aimed at to evaluate the catch rates, reproductive seasonality, size at first sexual maturity and gear selectivity pattern of Encrasicholina heteroloba, the widely exploited anchovy species on the west coast of Sri Lanka, in order to fill the knowledge gap of this data poor fishery.

\section{MATERIALS AND METHODS}

\section{Study site and fishery data collection}

Catch and the fishing effort data (active number of boats) of $E$. heteroloba were collected at the Negombo fish landing site $\left(7^{\circ} 12^{\prime} 37.22^{\prime \prime} \mathrm{N}, 79^{\circ}\right.$ 49'51.39" E), which is the main anchovy fish landing site on the west coast of Sri Lanka. Data were collected bi-weekly from January to December 2015. On each sampling day, 50-60\% of boats operated for the anchovy fishery were sampled randomly. Boats to be sampled were selected using a random number table and the total catch of E. heteroloba, gear information such as mesh size, number of net pieces used, were collected from each boat. Total length (TL) of $E$. heteroloba $(\mathrm{n}=2147)$ was measured to the nearest $0.1 \mathrm{~cm}$ using a measuring board and recorded with respect to the mesh size. Three samples of $E$. heteroloba each with $\sim 1 \mathrm{~kg}$ were collected randomly from the sampled boats to carry out reproductive biological studies.

Collected catch and effort data were used to calculate the catch rates (CPUE \pm SD in $\mathrm{kg}_{\text {boat }}{ }^{-1}$ day $^{-1}$ ). Monthly total catch (MTP in tonnes) was estimated using the following equation.

MTP $=$ CPUE $\times$ NFO $\times$ MRD

where,

MTP - Monthly total catch of E. heteroloba

CPUE - Mean catch rate of E. heteroloba

NFO - Average number of boats operated for the E. heteroloba fishery per day

MRD - Total number of fishing days for that particular month

\section{Reproductive biology}

In the laboratory, total length (TL), standard length (SD) and the total body weight (TW) of each individual $(\mathrm{n}=4340)$ were measured. Sex and gonad development stages were identified by dissecting and observing the gonads macroscopically (Ferreri et al., 2009). Monthly variation in sex ratio was estimated. Gonad weight and somatic weight of each dissected individual were measured separately and Gonado Somatic Index (GSI) was calculated using the following equation.

\section{GSI $\{$ (Gonad weight $) /($ Somatic weight $)\} \times 100$}

Percentage mature (Stage III and above) males and females in each length class were determined and from the plots of percentage maturity against length mean sizes at maturity or lengths at 50\% maturity $\left(L_{50}\right)$ of $E$. heteroloba were determined from a logistic curve fitted to the proportion $(P)$ of sexually mature males and females using the following equation (King, 2007).

$P=\frac{1}{\left[1+\exp \left[-r_{i}\left(L-L_{50}\right)\right]\right]}$

where, $L 50$ is the mean length at sexual maturity. $L 50$ was estimated by transforming this equation to linear form as follows:

$\ln [1-(1-P)]=r_{i} L_{50}-r L$

where, $r_{i}$ is the slope of the curve of the curve.

\section{Gillnet selectivity}

Collected mesh-wise length frequency data were used to estimate the gillnet selectivity pattern. Mesh-wise length data were raised to estimate the total frequency of each length class. The total length frequency data were adjusted for unit effort ( $F_{\text {adj }}$ ) as the number of fish for length class $L$, per $1000 \mathrm{~m}^{2}$ of gillnet per day.

Baranov-Holt method was used to analyze the adjusted length frequency data. In this analysis, it was assumed that the length frequency distribution of a fish species caught by two gillnets with slightly different mesh sizes exhibits the same standard deviation, same height of selection curves and similar fishing mortalities (Holt, 1963; Hamley, 1975). 


\section{N. M. P. S. Navarathne and D. C. T. Dissanayake}

According to Gulland (1983), the logarithms of catch ratios (in numbers) of overlapping regions of two gill nets with slightly different mesh sizes are linearly related to the length of the fish as;

Ln $\mathrm{C}_{2} / \mathrm{C}_{1}=\mathrm{a}+\mathrm{bL}$

where, $\mathrm{C}_{1}$ and $\mathrm{C}_{2}$ are $\mathrm{F}_{\text {adj }}$ in a length class in mesh sizes $M_{1}$ and $M_{2}$ respectively, and $a$ and $b$ are constants. The intercept (a) and the slope (b) of the equation 5 were used to determine the optimal length for each mesh size as follows: (Hamley, 1975).

For mesh size $\mathrm{M}_{1}$ :

$$
\mathrm{L}_{\mathrm{opt}(1)}=2 \mathrm{a} \cdot \mathrm{M}_{1} /\left[\mathrm{b}\left(\mathrm{M}_{1}+\mathrm{M}_{2}\right)\right]
$$

According to Hamley (1975), the standard deviation (SD) of both selection curves can be estimated as;

$\mathrm{SD}=\sqrt{\frac{2 \mathrm{a}\left(\mathrm{M}_{1}-\mathrm{M}_{2}\right)}{\mathrm{b}^{2}\left(\mathrm{M}_{1}+\mathrm{M}_{2}\right)}}$

When there were two estimates for $\mathrm{L}_{\mathrm{opt}}$ and $\mathrm{SD}$ for a given mesh size, the mean of these two values was taken. Using, $\mathrm{L}_{\text {opt(1) }}, \mathrm{L}_{\text {opt(2) }}$ and $\mathrm{SD}$ values, probabilities of capture $\left(\mathrm{P}_{1}\right.$ and $\left.\mathrm{P}_{2}\right)$ of length $\mathrm{L}$, in each mesh size $\left(M_{1}\right.$ and $\left.M_{2}\right)$ were estimated as per the following equation.

For mesh size $\mathrm{M}_{1}$ :

$\mathrm{P}_{1}=\exp \left[-\left(\mathrm{L}-\mathrm{L}_{\mathrm{opt}(1)}\right)^{2} / 2 \mathrm{SD}^{2}\right]$

\section{Statistical Analysis}

The statistical significance of sex ratio was assessed using the chi-square test $\left(\chi^{2}\right)$. The regression relationships between length and weight as well as GSI and body size were determined for male and female separately. All the statistical analyses were performed using $\mathrm{R}$ version 2.8.1 ( $\mathrm{R}$ Development Core Team 2015, http://www.rproject.org). Differences were considered significant at a probability level of 0.05 .

\section{RESULTS}

\section{The fishery}

$E$. heteroloba is mainly caught off the west coast of Sri Lanka using drift gillnets of $1.1 \mathrm{~cm}, 1.2 \mathrm{~cm}$ and $1.8 \mathrm{~cm}$ stretched mesh sizes. Fiberglass Reinforced Plastic (FRP) boats powered with 15 and $25 \mathrm{HP}$ outboard engines are used as the major fishing vessel. Normally, two fishermen are on board and they leave for fishing between $3.00 \mathrm{am}$ and 6.00 am and return to the coast around 8.00 am to $3.00 \mathrm{pm}$. Although accurate fishing positions are not available, fishing is carried out in the shallow coastal waters from $8-10 \mathrm{~km}$ away from the shore. The true fishing time varies from 15 minutes to 2 hours. As an average, $18 \pm 2$ net pieces are used in gill net fishing operation.

Monthly variation in the total number of FRP boats operated for the anchovy fishery off Negombo, Sri Lanka is shown in fig. 1. The highest fishing effort was recorded in October (2080 boats) and the lowest effort was in May (256 boats). Catch rates (CPUE) decreased gradually from February to May and started to increase since June reporting the highest CPUE in September $\left(150 \pm 66 \mathrm{~kg}\right.$ boat $\left.^{-1} \mathrm{day}^{-1}\right)$. The estimated total catch of E. heteroloba at the Negombo fish landing site from January to December 2015 was 751 tonnes (Fig. 2).

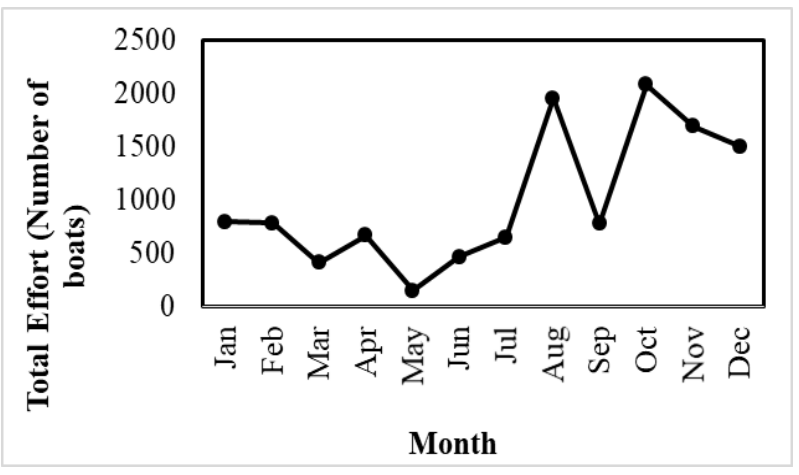

Fig 1 Monthly variations in total number of outboard fiberglass reinforced plastic (OFRP) boats operated for the anchovy fishery at the Negombo fish landing site, west coast of Sri Lanka

\section{Reproductive biology}

A total of 4340 specimens was sampled during the study period, of which 2296 were females and 2044 were males. The higher number of males than females were reported in April, May, June, August and October while females were dominant in the catches in the rest of the month (Table 1). The expected 1:1 sex ratio was observed only in September and the statistical analysis proved that sex ratio was significantly different from 1:1in 


\section{N. M. P. S. Navarathne and D. C. T. Dissanayake}

April, May, June, October and November $(\mathrm{p}<0.05$, $\chi^{2}$ test). Monthly variation in GSI (mean \pm SD) of male and female $E$. heteroloba was computed (Fig.3). GSI of males ranged from $0.60 \pm 0.45$ to
$2.38 \pm 0.64$ and in females it ranged from $1.22 \pm$ 0.42 to $3.22 \pm 0.53$. In both sexes, GSI gradually increased from January to July reporting the highest GSI in July.

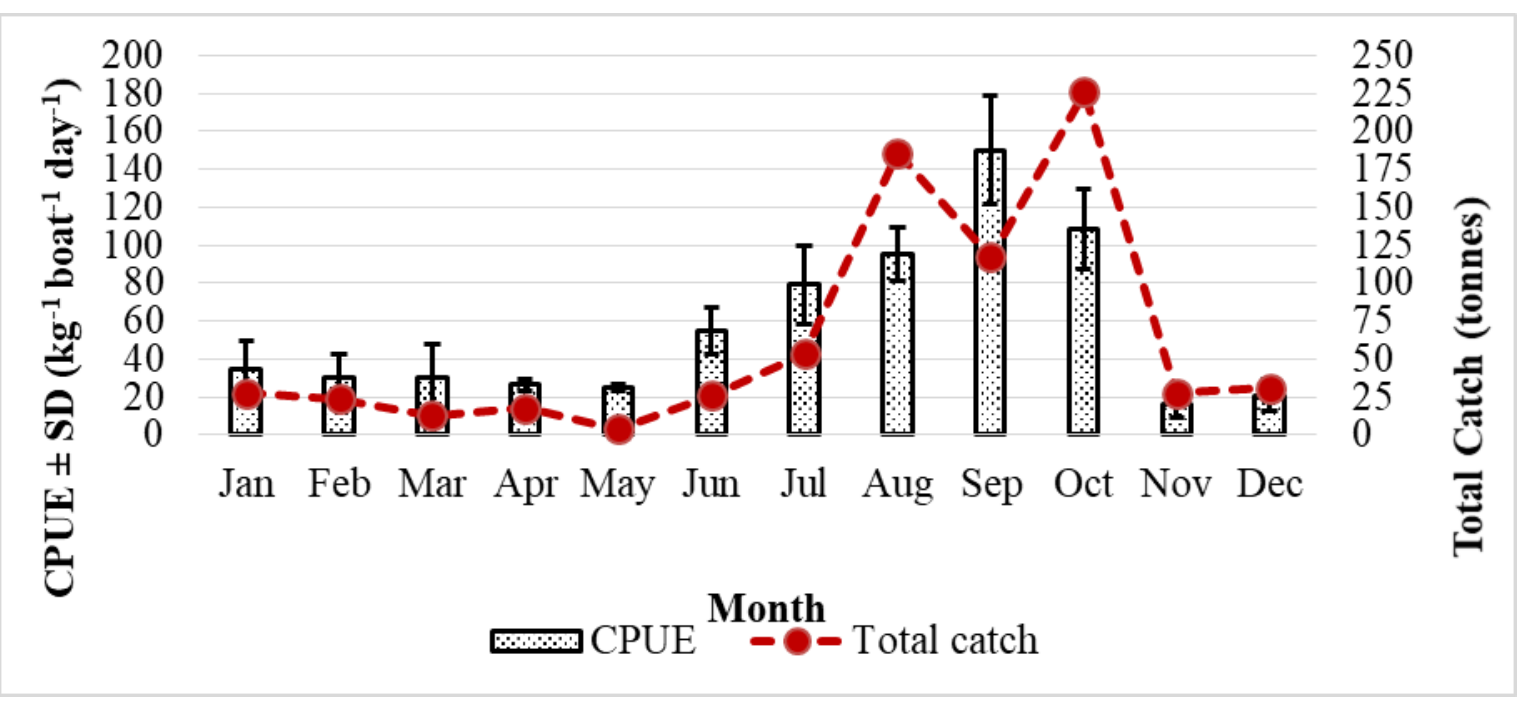

Fig. 2 Monthly variation in catch rates (CPUE $\pm \mathrm{SD}$ in $\left.\mathrm{kg}^{\text {boat }}{ }^{-1} \mathrm{day}^{-1}\right)$ and total catch (tonnes) of $E$. heteroloba landed at the Negombo fish landing site, west coast of Sri Lanka.

Table 1 Monthly variation in sex ratio (male: female) of E. Heteroloba landed at the Negombo fish landing site, west coast of Sri Lanka from January to December 2015. Number of E. Heteroloba (n) used to estimate sex ratio in each month are given within brackets.

\begin{tabular}{llc}
\hline \multicolumn{1}{c}{ Month } & \multicolumn{1}{c}{ Sex ratio (Male : female) } & P value \\
\hline January & $1.0: 1.1(n=310)$ & 0.65 \\
February & $1.0: 1.2(n=302)$ & 0.47 \\
March & $1.0: 1.1(n=403)$ & 0.65 \\
April & $1.0: 0.7(n=385)$ & 0.05 \\
May & $1.0: 0.5(n=346)$ & $0.00^{*}$ \\
June & $1.0: 0.5(n=383)$ & $0.00^{*}$ \\
July & $1.0: 1.05(n=365)$ & 0.78 \\
August & $1.0: 0.8(n=411)$ & 0.19 \\
September & $1.0: 1.0(n=394)$ & 0.78 \\
October & $1.0: 0.5(n=352)$ & $0.00^{*}$ \\
November & $1.0: 1.7(n=328)$ & $0.02^{*}$ \\
December & $1.0: 1.2(n=361)$ & 0.63 \\
\hline
\end{tabular}

$*$ Significant difference at a level of $95 \% ; \mathrm{p}<0.05$

A sharp declined in GSI was reported in August, but it made a small peak again in September and gradual declined in October (Fig. 3). Although, GSI varied with the body size, a significant relationship was not evident ( $p>0.05)$. However, males reported the highest GSI in the length range of $7.0-7.2 \mathrm{~cm}$ and for females it was in the length range of $9.1-9.3 \mathrm{~cm}$ (Table 2). Length weight relationship indicated that $E$. heteroloba had an isometric growth. 
N. M. P. S. Navarathne and D. C. T. Dissanayake

Figure 4 shows that E. heteroloba is sexually active throughout the year. Spawning individuals were evident throughout the study period with a peak in July. The highest percentage of 'spent females' was reported in August followed by October. This study revealed that size at first sexual maturity of $E$. heteroloba males was 7.40 $\mathrm{cm}$ (total length) while females attain sexually mature at $7.45 \mathrm{~cm}$ (Fig. 5).
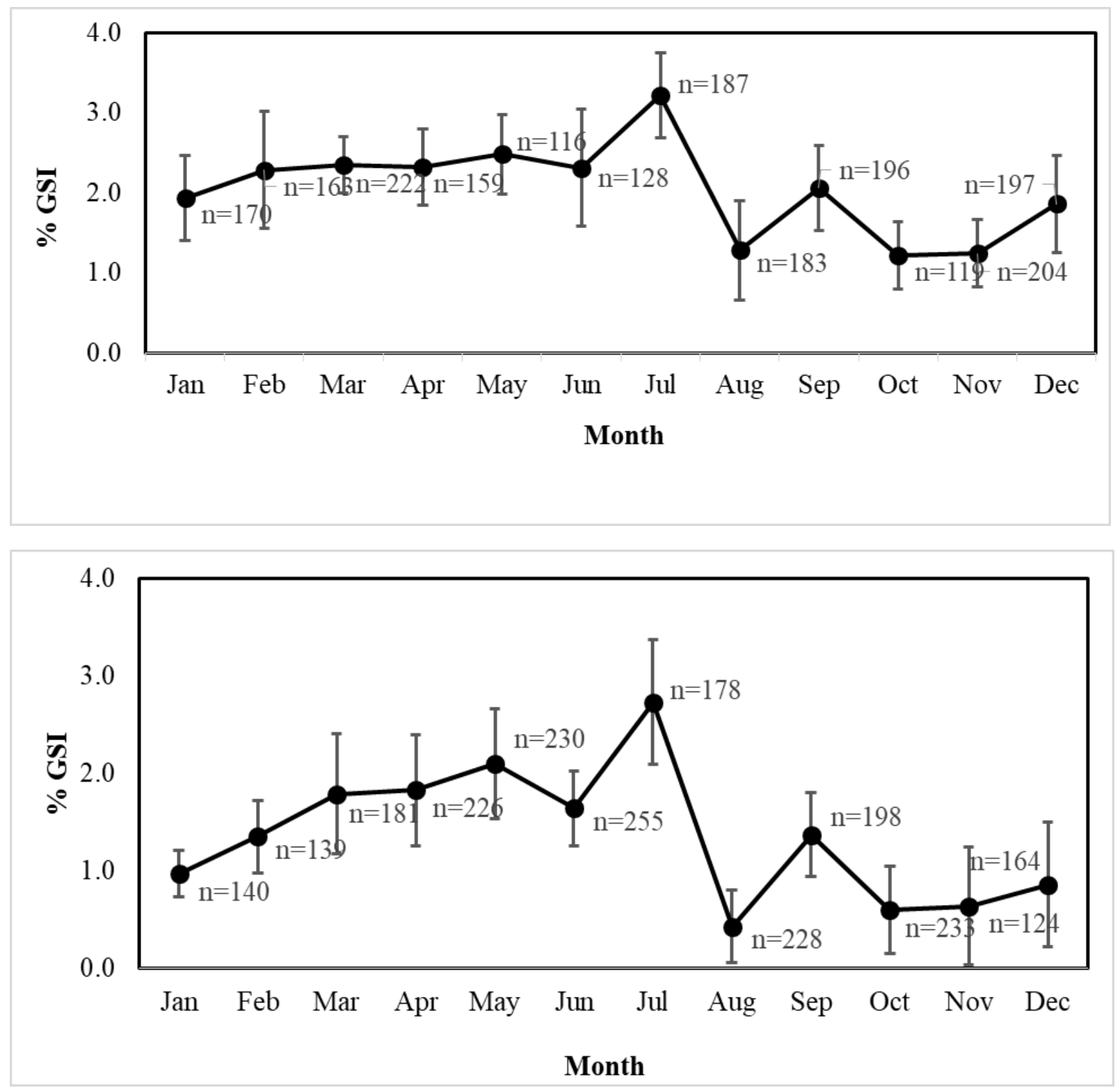

Fig 3 Monthly variation in GSI ( \pm SD) of E. heteroloba female (upper) and male (below) in the coastal waters off Negombo, Sri Lanka, from January to December 2015. 


\section{N. M. P. S. Navarathne and D. C. T. Dissanayake}

Table 2 Mean $( \pm$ SD) values for Body weight $( \pm$ SD), gonad weight $( \pm$ SD) and Gonado Somatic Index ( \pm $\mathrm{SD})$ males and females of different length groups of E. heteroloba in the coastal waters off Negombo, Sri Lanka. Number of males (n) and females (n) examined in each length group are given within brackets.

\begin{tabular}{|c|c|c|c|c|c|c|c|}
\hline \multicolumn{5}{|c|}{ Male } & \multicolumn{3}{|c|}{ Female } \\
\hline $\begin{array}{l}\text { Total length } \\
\quad(\mathrm{cm})\end{array}$ & $\begin{array}{c}\text { Mean } \\
\text { body } \\
\text { weight }( \pm \\
\text { SD) }(\mathrm{g})\end{array}$ & $\begin{array}{c}\text { Mean } \\
\text { gonad } \\
\text { weight }( \pm \\
\text { SD) }(\mathrm{g})\end{array}$ & $\begin{array}{l}\text { Mean } \\
\% \text { GSI } \\
( \pm \text { SD) }\end{array}$ & $\begin{array}{c}\text { Total } \\
\text { length }(\mathrm{cm})\end{array}$ & $\begin{array}{c}\text { Mean } \\
\text { body } \\
\text { weight } \\
( \pm \text { SD) } \\
(\mathrm{g})\end{array}$ & $\begin{array}{c}\text { Mean } \\
\text { gonad } \\
\text { weight }( \pm \\
\text { SD) }(\mathrm{g})\end{array}$ & $\begin{array}{l}\text { Mean } \\
\% \text { GSI } \\
( \pm \text { SD) }\end{array}$ \\
\hline $\begin{array}{l}5.5 .-5.7 \\
(n=133)\end{array}$ & $\begin{array}{c}1.20 \pm \\
0.17\end{array}$ & $\begin{array}{c}0.02 \pm \\
0.02\end{array}$ & $\begin{array}{c}1.67 \pm \\
0.94\end{array}$ & $\begin{array}{l}5.5 .-5.7 \\
(n=121)\end{array}$ & $\begin{array}{c}1.82 \pm \\
0.2\end{array}$ & $\begin{array}{c}0.03 \pm \\
0.01\end{array}$ & $\begin{array}{c}2.21 \pm \\
0.96\end{array}$ \\
\hline $\begin{array}{l}5.8-6.0 \\
(n=161)\end{array}$ & $\begin{array}{c}1.62 \pm \\
0.27\end{array}$ & $\begin{array}{c}0.03 \pm \\
0.02\end{array}$ & $\begin{array}{c}1.10 \pm \\
1.07\end{array}$ & $\begin{array}{l}5.8-6.0 \\
(n=163)\end{array}$ & $\begin{array}{c}2.08 \pm \\
0.39\end{array}$ & $\begin{array}{c}0.04 \pm \\
0.02\end{array}$ & $\begin{array}{c}2.01 \pm \\
0.91\end{array}$ \\
\hline $\begin{array}{l}6.1-6.3 \\
(n=153)\end{array}$ & $\begin{array}{c}1.73 \pm \\
0.22\end{array}$ & $\begin{array}{c}0.04 \pm \\
0.02\end{array}$ & $\begin{array}{c}1.05 \pm \\
1.38\end{array}$ & $\begin{array}{l}6.1-6.3 \\
(n=142)\end{array}$ & $\begin{array}{c}2.23 \pm \\
0.56\end{array}$ & $\begin{array}{c}0.04 \pm \\
0.02\end{array}$ & $\begin{array}{c}2.15 \pm \\
0.84\end{array}$ \\
\hline $\begin{array}{l}6.4-6.6 \\
(n=202)\end{array}$ & $\begin{array}{c}2.00 \pm \\
0.26\end{array}$ & $\begin{array}{c}0.04 \pm \\
0.02\end{array}$ & $\begin{array}{l}1.10 \pm \\
1.03\end{array}$ & $\begin{array}{l}6.4-6.6 \\
(n=214)\end{array}$ & $\begin{array}{c}2.20 \pm \\
0.54\end{array}$ & $\begin{array}{c}0.04 \pm \\
0.02\end{array}$ & $\begin{array}{c}2.01 \pm \\
0.77\end{array}$ \\
\hline $\begin{array}{l}6.7-6.9 \\
(n=211)\end{array}$ & $\begin{array}{c}2.27 \pm \\
0.32\end{array}$ & $\begin{array}{c}0.04 \pm \\
0.01\end{array}$ & $\begin{array}{c}1.69 \pm \\
0.76\end{array}$ & $\begin{array}{l}6.7-6.9 \\
(n=223)\end{array}$ & $\begin{array}{c}2.45 \pm \\
0.57\end{array}$ & $\begin{array}{c}0.04 \pm \\
0.02\end{array}$ & $\begin{array}{c}1.99 \pm \\
0.79\end{array}$ \\
\hline $\begin{array}{l}7.0-7.2 \\
(n=285)\end{array}$ & $\begin{array}{c}2.55 \pm \\
0.26\end{array}$ & $\begin{array}{c}0.05 \pm \\
0.03\end{array}$ & $\begin{array}{c}2.22 \pm \\
0.98\end{array}$ & $\begin{array}{l}7.0-7.2 \\
(n=257)\end{array}$ & $\begin{array}{c}2.69 \pm \\
0.52\end{array}$ & $\begin{array}{c}0.04 \pm \\
0.02\end{array}$ & $\begin{array}{c}1.75 \pm \\
0.73\end{array}$ \\
\hline $\begin{array}{l}7.3-7.5 \\
(n=219)\end{array}$ & $\begin{array}{c}2.64 \pm \\
0.23\end{array}$ & $\begin{array}{c}0.03 \pm \\
0.01\end{array}$ & $\begin{array}{c}1.26 \pm \\
0.71\end{array}$ & $\begin{array}{l}7.3-7.5 \\
(n=267)\end{array}$ & $\begin{array}{c}2.68 \pm \\
0.53\end{array}$ & $\begin{array}{c}0.04 \pm \\
0.02\end{array}$ & $\begin{array}{c}1.80 \pm \\
0.86\end{array}$ \\
\hline $\begin{array}{l}7.6-7.8 \\
(n=163)\end{array}$ & $\begin{array}{c}2.93 \pm \\
0.29\end{array}$ & $\begin{array}{c}0.03 \pm \\
0.01\end{array}$ & $\begin{array}{c}0.97 \pm \\
0.65\end{array}$ & $\begin{array}{l}7.6-7.8 \\
(n=296)\end{array}$ & $\begin{array}{c}3.02 \pm \\
0.35\end{array}$ & $\begin{array}{c}0.05 \pm \\
0.03\end{array}$ & $\begin{array}{c}1.90 \pm \\
1.08\end{array}$ \\
\hline $\begin{array}{l}7.9-8.1 \\
(n=162)\end{array}$ & $\begin{array}{c}3.55 \pm \\
0.35\end{array}$ & $\begin{array}{c}0.04 \pm \\
0.03\end{array}$ & $\begin{array}{c}1.05 \pm \\
0.81\end{array}$ & $\begin{array}{l}7.9-8.1 \\
(n=219)\end{array}$ & $\begin{array}{c}3.50 \pm \\
0.38\end{array}$ & $\begin{array}{c}0.06 \pm \\
0.03\end{array}$ & $\begin{array}{c}1.78 \pm \\
0.89\end{array}$ \\
\hline $\begin{array}{l}8.2-8.4 \\
(n=128)\end{array}$ & $\begin{array}{c}4.26 \pm \\
0.29\end{array}$ & $\begin{array}{c}0.06 \pm \\
0.03\end{array}$ & $\begin{array}{c}1.43 \pm \\
0.65\end{array}$ & $\begin{array}{l}8.2-8.4 \\
(n=164)\end{array}$ & $\begin{array}{c}3.83 \\
\pm 0.44\end{array}$ & $\begin{array}{c}0.08 \pm \\
0.03\end{array}$ & $\begin{array}{c}2.11 \pm \\
0.85\end{array}$ \\
\hline $\begin{array}{l}8.5-8.7 \\
(n=135)\end{array}$ & $\begin{array}{c}4.66 \pm \\
0.35\end{array}$ & $\begin{array}{c}0.07 \pm \\
0.02\end{array}$ & $\begin{array}{c}1.65 \pm \\
0.64\end{array}$ & $\begin{array}{l}8.5-8.7 \\
(n=142)\end{array}$ & $\begin{array}{c}4.36 \pm \\
0.47\end{array}$ & $\begin{array}{c}0.07 \pm \\
0.05\end{array}$ & $\begin{array}{c}1.82 \pm \\
1.12\end{array}$ \\
\hline $\begin{array}{c}8.8-9.0 \\
(\mathrm{n}=91)\end{array}$ & $\begin{array}{c}4.90 \pm \\
0.91\end{array}$ & $\begin{array}{c}0.08 \pm \\
0.04\end{array}$ & $\begin{array}{c}1.69 \pm \\
0.91\end{array}$ & $\begin{array}{c}8.8-9.0 \\
(n=78)\end{array}$ & $\begin{array}{c}4.8 \pm \\
0.79\end{array}$ & $\begin{array}{c}0.11 \pm \\
0.04\end{array}$ & $\begin{array}{c}2.42 \pm \\
0.65\end{array}$ \\
\hline $\begin{array}{c}9.1-9.3 \\
(n=0)\end{array}$ & - & - & - & $\begin{array}{c}9.1-9.3 \\
(\mathrm{n}=11)\end{array}$ & $\begin{array}{c}5.28 \pm \\
0.71\end{array}$ & $\begin{array}{c}0.15 \pm \\
0.03\end{array}$ & $\begin{array}{c}3.05 \pm \\
0.80\end{array}$ \\
\hline $\begin{array}{r}\text { Length- } \\
\text { relatio }\end{array}$ & $\begin{array}{l}\text { eight } \\
\text { hip }\end{array}$ & $Y=2.671$ & -1.7027 & $\begin{array}{r}\text { Length- } \\
\text { relatio }\end{array}$ & $\begin{array}{l}\text { eight } \\
\text { hip }\end{array}$ & $Y=2.6$ & -1.6208 \\
\hline
\end{tabular}


N. M. P. S. Navarathne and D. C. T. Dissanayake

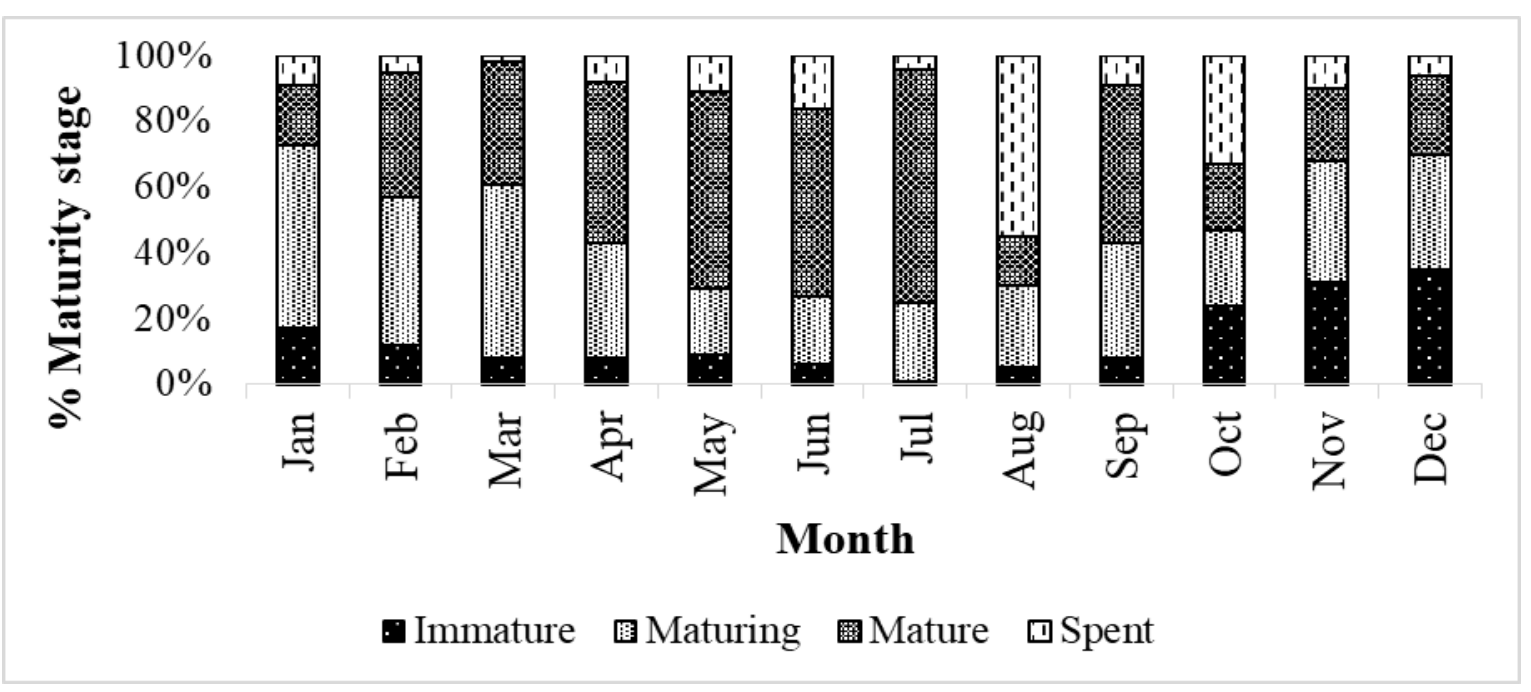

Fig 4 Monthly variations in maturity stages of $E$. heteroloba females in the coastal waters off Negombo, Sri Lanka from January to December 2015
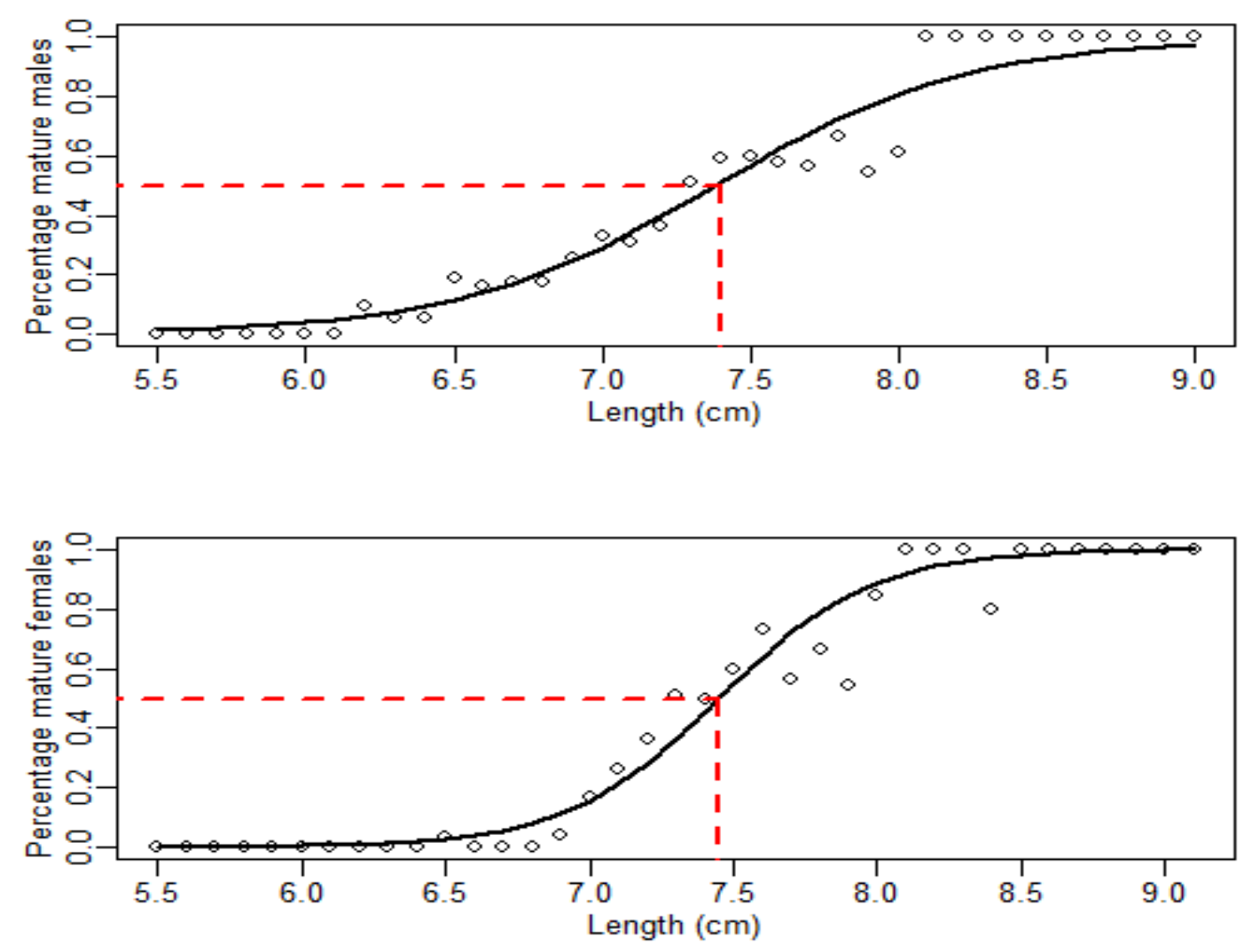

Fig. 5 Plots of percentage maturity of E. heteroloba against fish length for males (above panel) and females (below panel) in the coastal waters off Negombo, Sri Lanka. The mean length at maturity, i.e., length corresponding to $50 \%$ maturity $\left(\mathrm{L}_{50}\right)$ in each panel is shown as broken lines. 


\section{N. M. P. S. Navarathne and D. C. T. Dissanayake}

\section{Gillnet selectivity}

The regression relationships of logarithmic catch ratio of three mesh sizes $(1.0 \mathrm{~cm}, 1.2 \mathrm{~cm}$ and 1.8 $\mathrm{cm})$ against the corresponding midpoint of length classes are summarized in fig. 6. The estimated optimum length $\left(\mathrm{L}_{\mathrm{opt}} \pm \mathrm{SD}\right)$ of $E$. heteroloba for $1.0,1.2$ and $1.8 \mathrm{~cm}$ mesh gillnets were $5.60 \pm 0.62$, $6.42 \pm 0.79$ and $9.19 \pm 0.97 \mathrm{~cm}$, respectively. The selection range for $1.0 \mathrm{~cm}$ mesh size was 4.98 $6.22 \mathrm{~cm}$ and for $1.2 \mathrm{~cm}$ and $1.8 \mathrm{~cm}$ mesh sizes, these value ranges were $5.63-9.21 \mathrm{~cm}$ and 8.22 $10.16 \mathrm{~cm}$, respectively (Table 3). As there were two estimates for $\mathrm{L}_{\mathrm{opt}}$ and $\mathrm{SD}$ for the $1.2 \mathrm{~cm}$ mesh size, the mean value was taken. The gillnet selection curves plotted for three different mesh sizes are shown in fig. 7.

The estimated selection range for different mesh sizes was compared with the length range of $E$. heteroloba obtained from the commercial catches and their size at first sexual maturity. The results revealed that currently used gillnets with $1.0 \mathrm{~cm}(94 \%)$ and $1.2 \mathrm{~cm} \mathrm{(73 \% )} \mathrm{mesh} \mathrm{sizes} \mathrm{landed}$ very high percentage of immature individuals (Table 4). Further, the mean lengths of $E$. heteroloba landed by $1.0 \mathrm{~cm}$ and $1.2 \mathrm{~cm}$ mesh sizes were below the estimated size at first sexual maturity.
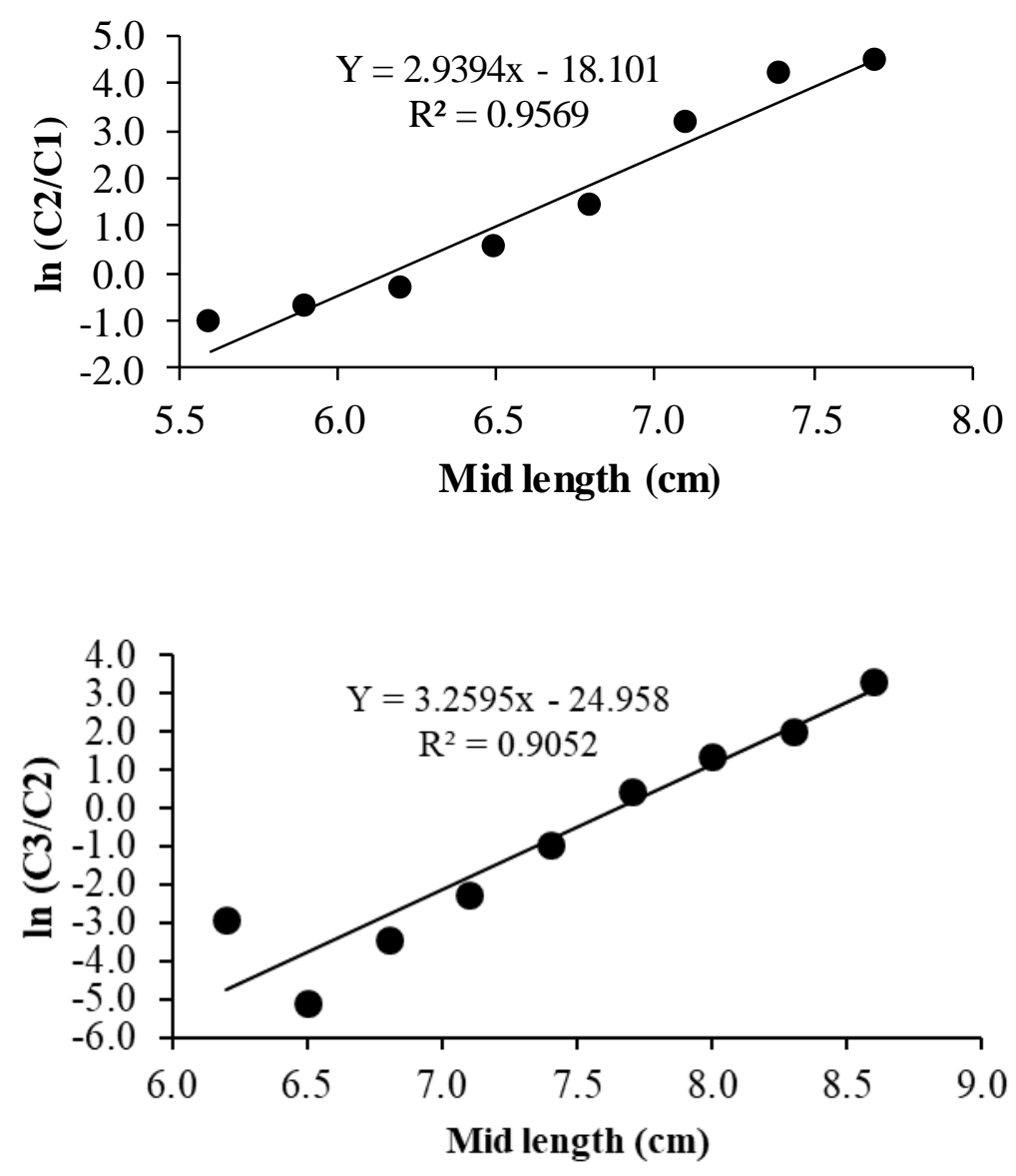

Fig. 6 Regression relationships of ln catch ratio against total length (mid length) of E. heteroloba. C1, C2 and $\mathrm{C} 3$ are catches in numbers (i.e. adjusted frequencies) in mesh size $1(1.0 \mathrm{~cm})$ mesh size $2(1.2 \mathrm{~cm})$ and mesh size $3(1.8 \mathrm{~cm})$, respectively. 


\section{N. M. P. S. Navarathne and D. C. T. Dissanayake}

Table 3 Some parameters of gear selectivity of E. heteroloba for three different gill net mesh sizes in the in the coastal waters off Negombo, Sri Lanka.

\begin{tabular}{llll}
\hline Aspects & \multicolumn{3}{c}{ Mesh sizes } \\
\cline { 2 - 4 } & $1.1 \mathrm{~cm}$ & $1.2 \mathrm{~cm}$ & $1.8 \mathrm{~cm}$ \\
\hline Optimum length $( \pm \mathrm{SD})$ & $5.60 \pm 0.62$ & $6.42 \pm 0.79$ & $9.19 \pm 0.97$ \\
Selection range $(\mathrm{cm})$ & $4.98-6.22$ & $5.63-9.21$ & $8.22-10.16$ \\
CPUE (catch per boat per day) & $19 \pm 5$ & $22 \pm 5.5$ & $15 \pm 16$ \\
Exploited length range & $5.0-7.8$ & $5.5-8.7$ & $7.1-10.0$ \\
Overall mean total length & $6.3 \pm 0.4$ & $7.0 \pm 0.5$ & $8.2 \pm 0.6$ \\
Overall \% of specimens $<\mathrm{L}_{50}$ & $94 \%$ & $73 \%$ & $4.4 \%$ \\
\hline
\end{tabular}

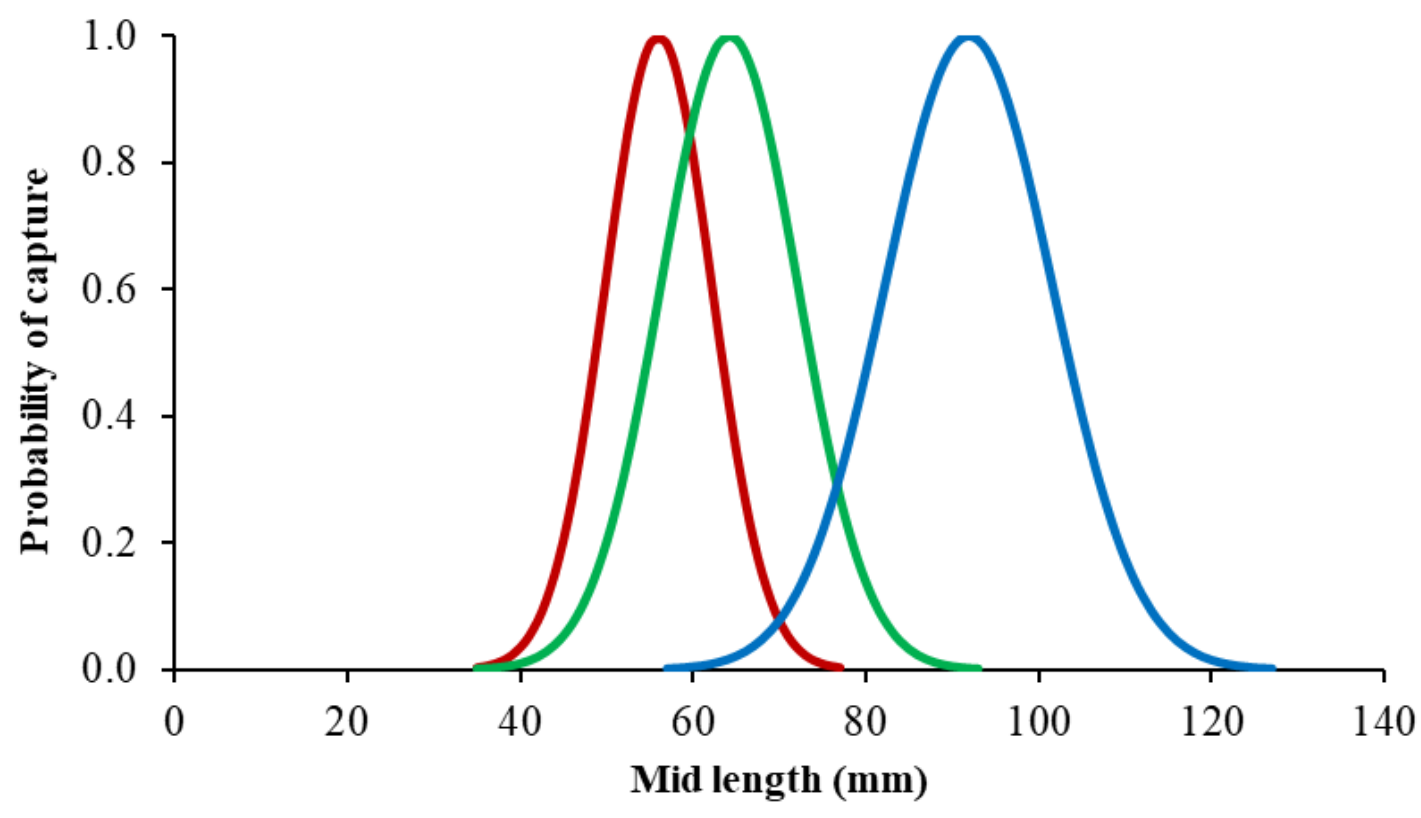

$-1.0 \mathrm{~cm}-1.2 \mathrm{~cm}-1.8 \mathrm{~cm}$

Fig 7 Gill net selection curves of E. heteroloba exploited by $1.0 \mathrm{~cm}, 1.2 \mathrm{~cm}$ and $1.8 \mathrm{~cm}$ stretch mesh sizes in the coastal waters off Negombo, Sri Lanka

\section{DISCUSSION}

E. heteroloba is considered as one of the important species in the coastal small pelagic fishery of Sri Lanka due to its contribution to the total marine capture fishery production and coastal livelihood. However, no scientific studies related to aspects of fishery, biology and stock assessment of this species have been carried out so far.

Different types of fishing gear are used to exploit this species in many parts of the world. Seines and stake nets are widely used in the
South China Sea (Carpenter et al., 1997) and traditional or small scale purse seines and beach seines are famous in Iran. The most popular gear types in the Philippines waters include beach seine, ring net, drift gillnet, bagnet, liftnet, modified Danish seine, filter net, and trawl (Khan, 2000; Luther, 1979). This study revealed that small mesh gill nets are widely used off the west coast of Sri Lanka off Negombo. 
From the present study, a seasonal variation in fishing effort and CPUE was evident and very low fishing effort and CPUE were reported from May to July. This could be due to rough sea condition prevailed this period with the onset of the southwest monsoon (May to September). Similar observations have been made earlier for some other small pelagic species off the west coast of Sri Lanka (Dissanayake and Sigurdsson, 2005; Karunasinghe and Wijeyaratne, 1995). Further, Luther (1979) reported the highest and lowest engraulid catches in the coastal waters off India in October $\left(241.349 \times 10^{3} \mathrm{~kg}\right)$ and May $\left(3.003 \times 10^{3}\right.$ $\mathrm{kg}$ ), respectively. According to Imran (2014), engraulid catches were very low during the east monsoon season in Krueng Raya Bay-Ache, Indonesia.

As the fishery for E. heteroloba is confined to limited geographical regions and as this species is mainly landed together with many other engraulid and Sardinella species, very limited information on the fishery and biology of E. heteroloba is available. As grouped or lumped catch data is available in many regions, including South Vietnam, South China Sea, the Philippines and Persian Gulf (Carpenter et al., 1997), it is difficult to make comparison with the current catch estimates. However, it was reported that, in the Philippines, the nominal CPUE of this species for the ring net fishery has fluctuated between 20 - 225 $\mathrm{kg}$ boat $^{-1}$ day $^{-1}$ since 2003 (BFAR-NFRDI 2017) and their values were higher than the CPUE values of the present study $\left(17-150 \mathrm{~kg}_{\text {boat }}{ }^{-1}\right.$ day $\left.^{-1}\right)$.

This study revealed a significant difference in 1:1 sex ratio in some months of the year and similar results have been recorded in previous studies (Laroche and Richardson, 1980; Millan, 1999). Although the exact reason for this observation could not be pointed out, differences in migratory pattern and habitat preferences of males and females, may be possible reasons for this effect.

According to Dalzell (1987), engraulids spawn throughout the year, particularly near the equator, with seasonal peaks associated with climatic conditions such as the monsoons. The present study also supports this finding as peak spawning of E. heteroloba occurred during the southwest monsoon period. According to Mohanth et al. (2004) mature anchovies were in the Indian coast throughout the year, but mature females with advanced stage of ovary were observed only from
July to August. Only few studies have been done to estimate the size at first sexual maturity of $E$. heteroloba and Aripin and Showers (2000) reported that they attain sexual maturity at $7.00 \mathrm{~cm}$ in the Philippines waters and the $\mathrm{L}_{50}$ value estimated in this study was not much deviated from this value.

Fisheries managers always promote the use of selective fishing gear as catching of undersized fishes can be controlled by adjusting either mesh or hook sizes (Fonseca et al., 2005). A mesh size selectivity of stationary lift net was reported for Stolephorus commersonii in Sorsogon Bay in the Philippines (Alba et al., 2016) and selectivity of mid-water trawls was studied for Engraulis encrasicolus in the Mediterranean (Stewart, 2001). This study estimated the gillnet selectivity pattern of E. heteroloba off the west coast of Sri Lanka.

This study has shown that currently used gill nets with $1.0 \mathrm{~cm}$ and $1.2 \mathrm{~cm}$ mesh sizes caught high percentages of immature E. heteroloba. Therefore, limiting of the use of these gill nets to catch E. heteroloba off the west coast of Sri Lanka is suggested to minimize catching immature fish. Although some scientists argued that the management of anchovies cannot be considered in isolation in a tropical multispecies fishery (Kurup and Ravindran, 2006), the proposed measure will be useful to manage a localized and targeted fishery like E. heteroloba fishery in this study. According to the local fisheries statistics, engraulid species make the second highest contribution to the total small pelagic landings in the country (MFAR, 2015) and E. heteroloba is considered as one of the dominant species in the catches. Therefore, management of this fishery is a timely requirement specially to sustain the livelihood of small-scale coastal fishers in this region. Due to lack of time series data, this study focused only to estimate the catch rate and reproductive pattern of $E$. heteroloba, but assessment of stock status and level of exploitation based on yield-per-recruit approaches is recommended to implement more robust measures to manage this fishery. However, short-lived species with smaller body size having high turnover rates can withstand high fishing pressure. On the other hand, recruitment failures caused by climatic variability were reported to occur in pelagic fisheries in the world (Walsh et al. 1980). 


\section{REFERENCES}

Alba, E. B., M. B. Chiuco and M. C. Rubia (2016). Mesh size selectivity of boat seine and stationary lift net for catching anchovy and white sardine in Sorsogon Bay, Philippines. International Journal of Fisheries and Aquaculture Studies 4(2): 265-273.

Anger, K. (2006). Contributions of larval biology to crustacean research: a review. Invertebrate Reproduction and Development 49(3): 175-205. https://doi.org/10.1080/07924259.2006.965220 7

Aripin, I. E. and P. A. T. Showers (2000). Population parameters of small pelagic fishes caught off Tawi-Tawi, Philippines. Naga 23(4): 21-26.

BFAR-NFRDI (2017). National Stock Assessment Program Technical Report, Bureau of Fisheries and Aquatic Resources -National Fisheries Research and Development Institute, The Philippines. $17 \mathrm{pp}$

Barange M., J. Coetzee J, A. Takasuka A, K. Hill, M. Gutierrez, Y. Oozeki, C. V. D. Lingen and V. Agostini (2009). Habitat expansion and contraction in anchovy and sardine populations. Progress of Oceanography 83: 251-260. https://doi.org/10.1016/j.pocean.2009.07.027

Chayrakul R. (1996). Larvae and juveniles fishes occurring in the Gulf of Thailand. Technical Paper of Marine Resources Survey, 1990, 98$120 \mathrm{pp}$.

Carpenter, K.E., F. Krupp, D. A. Jones and U. Zajonz (1997). FAO species identification guide for fishery purposes. The living marine resources of Kuwait, eastern Saudi Arabia, Bahrain, Qatar, and the United Arab Emirates. Rome (FAO), 293 pp

Dalzell, P. (1994). Whitebait or stolephorid anchovies. SPC Fisheries Newsletter 68: 20-23.

Dissanayake, D.C.T. and T. Sigurdsson (2005). Monitoring and assessment of offshore fishery in Sri Lanka. Report submitted for the United Nations University Fisheries Training Programme, $45 \mathrm{pp}$

Ferreri, R.; G. Basilone, M. Elia, A. Traina, F. Saborido-Rey and S. Mazzola (2009). Validation of macroscopic maturity stages according to microscopic histological examination for European anchovy. Marine Ecology 30(1): 181-187. https://doi.org/10.1111/j.14390485.2009.00312.x
Ad D. C. T. Dissanayake

FAO (2018). The state of world fisheries and aquaculture: meeting the sustainable development goals. Food and Agriculture Organization of the United Nations Rome, pp. 277

Gulland, J. A. (1983). Fish Stock Assessment: A Manual of Basic Methods. John Wiley, New York. 223 p.

Fonseca, P., R. Martins, A. Campo and P. Sobral (2005). Gill-net selectivity off the Portuguese western coast. Fisheries Research 73: 323-339. https://doi.org/10.1016/j.fishres.2005.01.015

Hamley, J.M. (1975). Review of gillnet selectivity. Journal of Fisheries Research Board of Canada 32: 1943-1969. https://doi.org/10.1139/f75-233

Holt, S.J. (1963). A method for determining gear selectivity and its application. ICNAF Special Publication 5: 106- 115.

Imran, Z. and M. Yamao (2014). Overfishing of the Anchovy Fisheries in Krueng Raya BayAceh, Indonesia. Proceedings of the Seventeenth International Conference of the International Institute of Fisheries Economics and Trade (IIFET), p31.

Karunasinghe, N. and M. J. S. Wijeyaratne (1995). Effects of Monsoonal currents, rainfall and lunar phase on the abundance of Amblygaster sirm in the coastal waters off Negombo, Sri Lanka. Sri Lanka Journal of Aquatic Sciences 1: 53-58.

Khan, M. Z. (2000). Fishery, biology and resource characteristics of golden anchovy, Coilia dussumieri (Cuv and Val). Marine Fisheries Research and Management 1: 310-316.

King, M. (2007). Fisheries Biology, Assessment and Management, $2^{\text {nd }}$ ed. Oxford, UK, Blackwell Publishing, $382 \mathrm{p}$. http://dx.doi.org/10.1002/9781118688038

Kurup, B.M. and K. Ravindran (2006). Status, prospects and management of pelagic fisheries in India. Proceedings of the international symposium on improved sustainability of fish production systems and appropriate technologies for utilization, 354-376 pp

Laroche, J. L. and S. L. Richardson (1980). Reproduction of Northern anchovy, Engraulis mordax, off Oregon and Washington. Fisheries Bulletin, 78(3), 603-618.

Lavoue S., M. Miya and M. Nishida (2010). Mitochondrial phylogenomics of anchovies (family Engraulidae) and recurrent origins of pronounced miniaturization in the order 
N. M. P. S. Navarathne and D. C. T. Dissanayake

Clupeiformes. Marine Fisheries Research and Management 56: 480-485.

https://doi.org/10.1016/j.ympev.2009.11.022

Luther, G., 1979: Anchovy fishery of southwest coast of India with notes on characteristics of the resources. Indian Journal of Fisheries, 26(1), 23-36.

Millan, M., 1999: Reproductive characteristics and condition status of anchovy Engraulis encrasicolus L. from the Bay of Cadiz (SW Spain). Fisheries Research, 41, 73-86. https://doi.org/10.1016/S0165-7836(99)00010-

7

MFAR (2015) Statistics on fisheries, Sri Lanka. Ministry of Fisheries Aquatic Resources, Sri Lanka. Available at www.fisheries.gov.lk

Mohanty, P.K., S. S. Khora, U. S. Panda, G. N. Moha patra and P. Mishra (2004). An Overview of Sardines and Anchovies Fishery along Indian Coasts. Department of Marine Sciences, Berhampur University, Orissa. 9 p.

R Development Core Team 2015, http://www.rproject.org

Santaclara J. F., A.G. Cabado, and J.M. Vieites (2006). Development of a method for genetic identification of four species of anchovies: $E$. encrasicolus, E. anchoita, E. ringens and E. japonicas. European Food Research and Technology 223: 609-614.

https://doi.org/10.1007/s00217-005-0241-5

Stewart, P.A.M. (2001). A review of studies of fishing gear selectivity in the Mediterranean. Food and Agriculture Organization of the United Nations, Rome. pp 57.

Walsh, J.J., T.E.Whitledge, W.E. Esaias, R.L. Smith, S.A. Huntsman, H. Santander and B.R.De Mendiola (1980) The spawning habitat of the Peruvian anchovy, Engraulis ringens. Deep Sea Research Part A. Oceanographic Research Papers 27: 1-27.

https://doi.org/10.1016/0198-0149(80)90069 